\title{
Primary Discrimination and Application of Real Estate Investment Trust and Real Estate Private Equity Funds
}

\author{
Yun Hua \\ School of Urban Planning and Management \\ Harbin Institute of Technology Shenzhen Graduate School, Shenzhen 518055, China \\ E-mail: hjpph@126.com
}

Received: April 27, 2011 Accepted: May 13, 2011 doi:10.5539/ibr.v4n3p188

\begin{abstract}
In recent years, because of more strict credit policies, the traditional financing channels of real estate have been limited. Both the real estate investment trusts (REITs) and the real estate private equity funds (REPE) have been new financial channels. The concepts about REITs and REPE are discriminated in detail in this article, and the application feasibility of REITs and REPE in China is discussed, and relative advices are proposed aiming at the application obstacles in China.
\end{abstract}

Keywords: Real estate, Investment trusts, Private equity (PE), REITs

\section{Introduction}

Real estate is the high-lever industry, and the own resources of most real estate development enterprises in China don't exceed 20\%, seriously depending on the loan from banks and other capital sources. In 2010, the new increment of real estate loan in financial institutions was 20.2 thousand billion Yuan, and the proportion in all new increments of loan of RMB was $25.4 \%$. In the period of "twelfth five-year plan", the planned guarantee house quantity will be 36 million, which needs a great quantity of construction capital. Only in 2011, the construction of guarantee housing will need the investment of 13-14 thousand billion Yuan.

At present, the monetary policy environment is frapped continually, the credit of financial institutions is stricter and stricter, and many traditional financing channels such as ban loan, trust loan, and debt issuance only can step forward hardly. Based on that, REITs and REPE become possible new financial channels. But existing literatures have not discriminated these two kinds of financing mode clearly, and the practical applications have also been interfered because of promiscuous concepts.

\section{Concept discrimination of REITs and REPE}

\subsection{Basic concepts}

REITs occurred in USA in 1960, and it means that the trust institutions issue the benefit certificates of the real estate investment trusts to the public or the directional private placements for financing. The capitals financed are used to purchase the target real estate (i.e. equity-type REITs), or offer loans for the real estates, or invest the debts for the mortgage of real estate (i.e. mortgage-type REITs), and the earned benefits will be distributed to investors as the stock dividends. In USA, the equity-type REITs is the representative form of REITs, and these real estates with incomes form possess and operation, such as the office block, the shopping center, the hotel, the apartment, and the industrial plant, and the rents of these real estates will be distributed to the investors according to corresponding proportions. REITs mainly means the listed capitals in the market, but if the capitals can be issued privately if they accord with the regulations of the REITs of USA. The REITs in this article means the listed REITs.

REPE (Real Estate Private Equity) is to collect capitals by the private placement way for a few institutional investors with risk identification and bearing capacity, or special individual investors. It invests in the real estate enterprises unlisted in the market by the equity investment way, and offers the management service, to obtain the returns by selling the hold shares when the invested real estate enterprises will be listed publicly in the future, or be purchased by the merger and acquisition way, or be bought back.

REITs and REPE are easy to be confused with the concept of Chinese real estate investment funds, and REITs is the securitized industrial investment fund, and it is a kind of standard and special form in the trust forms of the real estate investment fund. The real estate investment trust fund of China gives priority to offer loans for real estate development enterprise, and it is not like the standard REITs in USA. REPE belongs to the real estate investment fund, but REPE specially means the investment mode giving priority to the equity investment form through the 
private offering mode. Concretely speaking, both funds are obviously different in many aspects such as organizational form, placement establishment, investment direction, equity proportion, operation, and quit, which are discriminated in detail as follows.

\subsection{Organization form}

REITs mainly adopt the corporate system and the trust system, and REPE adopts the trust system, the corporate system, and the limited partnership system. Though REPE may be the corporate system and the trust system, but most of them exist by the limited partnership form.

\subsection{Establishment by offering}

Listed REITs are established by the way of public offering, and REPE is established by the way of private offering. Like the public issuance of stocks, the public offering mode needs issue relative offering documents according to the laws and regulations of the listed place, and the requirements of the exchange, and the investors faced by the public offering mode may be the investors with the securities accounts. But the offering mode of REPE gives priority to institutional investors and specific individuals, including banks, pension funds, insurance companies, listed companies, and unlisted large-scale group companies. The principal legal documents of the limited partnership system-type REPE, the corporate system-type REPE, and the trust system-REPE respectively are the partnership agreement, the articles of incorporation, and the memorandum in writing. The key of successful REITs offering is in the profitability of object assets, and most REITs will be offered successfully. And the key of successful REPE offering is in the influence of the offering institutions, largely influenced by the situation of the capital market, and the risk of failure is large.

\subsection{Investment direction}

The investment direction of REITs and REPE is real estate. But the strict REITs must possess the object assets first, and collect capitals based on the value of these object assets, so the investment direction and object of REITs are very clear, and generally, the investment object only gives priority to one item. For example, the YUEXIU REIT in HKEx clearly includes four real estates, i.e. the White Horse Trading Mansion, the Victoria Square, the Urban Construction Mansion, and the Fortune Mansion. But REPE belongs to industrial investment funds, and when collecting the capitals, it is not required that the capitals are invested to certain one object, but only certain type of asset (real estate) or industry.

REPE only needs macro industrial investment plan or many selectable real estate investment objects, and after the capitals are collected successfully, REPE will seek proper real estate investment object, and carefully survey and demonstrate concrete objects to decide the final investment, and the investment objects of fund give priority to many items. For example, the initial scale of the real estate fund collected by Shenzhen Capital Group Co., Ltd would exceed 0.5 billion Yuan, and the company would cooperate with the large-scale real estate enterprises first. In the first phase real estate fund initiated by Gemdale and UBS, the capital scale would exceed 0.1 billion dollars, which would be mainly used in the projects developed by Gemdale. Gemdale would first select the projects which need be invested, then its partners would determine the investment.

In short, though both REITs and REPE invest in real estate, but the object assets of REITs is clearer, and REITs first seek assets and then collect capitals, but the object assets of REPE is not certainly definite, and REPE first collects capitals and then seeks the assets.

\subsection{Proportion of rights and interests}

Both REITs and REPE give priority to equity investment, and they all possess the equity of the invested objects, but the equity proportions are different. REITs generally possess all stock equity of invested objects, but REPE only possesses part of stock equity of the invested objects, and most REPEs only occupy minority interest. Because of the difference of the stock equity proportions, both parties play different roles in the invested enterprises. REITs completely operate the assets of the invested object, and actively manage the assets. Because REPE only possesses minority or most stock equity, it only participates in the management of the invested object, and the initiative of the operation is always grasped by the management level of the enterprise. Even if REPE occupies the holding position, it may not control the operation of the invested object. Most roles of REPE are to support, assist, professionally serve the invested enterprise, and enhance the value of the enterprise, and it only control some key factors by the seats of the directors board or the voting right.

\subsection{Operation and exit}

Strict REITs are standardly negotiable financial products, and REITs purchase the asset package of real estate from the listed or non-listed companies, and strictly restrain the sale of assets, and most incomes come from the rent 
income, mortgage interest of real estates, or the income of selling real estates, and REITs can circulate in the market of the stock exchange, with high mobility. Investors can purchase or sell REITs in the market to realize the exit. Therefore, REITs have some characteristics of listed stocks, and the income is relatively more stable than the income of stock, and the income is between the stock and the bond.

REPE belongs to the non-standard investment mode, and it generally invests in the non-listed real estate assets, and most incomes come from the capital appreciation after quitting, only a few of incomes come from the operation income of the real estate assets. The best exit mode of REPE is the IPO $\mathrm{f}$ invested enterprises. Second, the management layer can purchase, transfer the assets to other investors through merger or liquidation, but the return rate is not higher than the return rate of IPO. In addition, the subordinate companies of many REPE investment enterprises of real estate in China realize the exit by appointing the yearly yield. Totally, the mobility of stock equity of REPE is bad, with higher risk, so the stock holders require higher investment return rate, and once IPO is realized, tens of times of capital increment can be obtained.

\subsection{Others}

There are still many differences between REITs and REPE. For example, the dividend payment proportion of REITs is higher, and the payment proportion of REPE before exit is lower. Because REITs are required to be listed publicly, the information disclosure is limited, and REPE needs not disclose its information because it is issued privately. Once REITs come into the market, they can be traded, but REPE has the closing period from one year to ten years. In the closing period, investors cannot withdraw the capital fund. REITs can be managed with a loan, but that is rare in REPE. In Sep, 2010, the asset-liability ratio of the assets of REITs in USA was $50.7 \%$ averagely.

\section{Application feasibility of REITS and REPE}

\subsection{The traditional financing channel of real estate is limited, and new financing modes have occurred}

Since the State Council of China implemented the control to real estates in 2003, it has issued a series of policies to strictly control the high housing price and the real estate credit, and the financing channels of the real estate enterprises have been strictly limited. At the end of 2010, to control the credit of real estate, CBRC (China Banking Regulatory Commission) issued the "Notice of the General Office of CBRC about the Risk Clue of the Real Estate Trust Business for Trust Companies", and performed the risk clue to the real estate trust business of the trust companies, and required that the trust companies to check and inspect the real estate trust business. At the same time, the central bank also continually enhanced the deposit reserve ratio and the deposit and loan rates, and since 2011, it has enhanced the deposit reserve ratio four times, and enhanced the deposit reserve ratio two times, and the reserve ratio of large scale financial institutions has been enhanced to $20.5 \%$, and the loan rate has been enhanced to $6.31 \%$.

Except for strict shrinking credit policies, traditional financial measures are also been limited. The IPO and the back-door listing of Chinese real estate enterprises have been suspended. The issuance increment, the allotment of shares, and the bond issuance also have been stopped. The trust of real estates also faces increasingly strict policies. According to the survey of relative supervision institutions for 60 large real estate enterprise groups in the Nov of 2010 , the average asset-liability ratios of 18 groups had exceeded $70 \%$, and the asset-liability ratios of 64 member enterprises have exceeded $90 \%$, and high liability ratio has make the financing channel become extremely difficult by the traditional channel. In this background, diversified financing measures have become the urgent demands for real estate enterprises, and the private equity fund of real estate has been the important financing channel sadly, and the financing mode of REITs in the international market has been noticed increasingly.

\subsection{REITs in the international market develop maturely, and the primary products of REITs have been developed in} China

\subsubsection{REITs in the international market develop maturely}

REITs have been the important financing tool for the real estates in the international market, and REITs have been developed above 50 years in USA, and the matching system of policies is perfect, and the market is developed. According to the update statistic of the US State Real Estate Investment Trust Fund Association, up to Feb of 2011, there were 155 listed REITs in USA, with the total value of 430 billion dollars. The development of REITs can follow the international experiences, and the REITs products listed in the international market all can be the models of the REITs in China for development.

\subsubsection{The trust scale of real estate of China is big enough to make experiments for REITs}

In the mainland of China, though there are not products of REITs, but the primary products with similar financing function, i.e. the real estate trusts, have certain scale, and they has been the important financing channel for the real estate industry, which has established good base for the push of REITs. 
Other than REITs, the real estate trust adopts the non-public offering mode, and it mainly engages in the loan of real estate and the product time limit generally cannot exceed three years. It has the loan function of non-representative mortgage REITs. According to the statistic of the Chinese Trust Industry Association, up to 2010, the surplus of the capital trusts investing in the real estates was 432.4 billion Yuan, $15 \%$ of all industries. The data of Yick Wealth showed that from Jan to March in 2011, 592 trust products had been issued, and the trust issuance of real estates increased month to month, and the quantity achieved $178,30 \%$ of the total quantity.

In China, REITs have been experimented, and Tianjin, Beijing, Shanghai, and Hainan have acquired the certificate of experimental unit, and the final experiment plan has not been authorized by the State Council of China. Guangdong Province also definitely supported the experiment work of REITs of public renting houses, and GFIH is studying the experiment plan of public renting house REITs, and preparing for the application of the experimental unit of REITs.

\subsection{Good development tendency of REPE in China}

In the situation that the policies are shrinking increasingly, the scale of the private equity fund of real estate raises largely. According to the data of Qing Branch Research Center, in 2006, there were 31 cases of private equity investment in the real estate industry, and the investment amount achieved 3.037 billion dollars, $46.6 \%$ of the total investment of traditional industries. Million Date showed that from Jan to Nov in 2010, 10 real estate private funds successfully collected 1.859 billion Dollars in China, and the fund quantity and amount respectively were 5 times and 3.4 times of the yearly level in 2009. Many big companies and real estate enterprises also became the sponsors of REPE, such as the real estate fund with the scale about 0.25-5 billion dollars founded by China Overseas and ICBC International, the China Resources International Real Estate Fund and the China Resources Islamic Fund. Some rich and powerful people or corporate executives also invested their assets to the real estate funds, for example, the founders of the Flourish China Real Estate Investment Fund included the president of the Sunny 100 Estates Group and the President of Forte Group.

Foreign capitals also quicken the investments of RMB investment fund and occupy the business of real estates. In 2010 many cases that the foreign capitals including sovereign funds cooperated with Chinese real estate enterprises to develop the real estate projects occurred one by one. In Sep, the private equity fund of USA, Blackstone cooperated with Hong Kong Great Eagle Holdings to develop the High-end hotels and buildings together in Dalian. In Nov, The GTC Galleria of Holland was completed in Chengdu and begun to do business. In the middle of Dec, Cosco Group sold its all stock equities of Sino-Ocean Land to the foreign capital funds belonging to Hong Kong Nan Fung Group and HSBC. In the late of Dec, three foreign companies including Kerry Holdings, Wilmar International, and Shangri-La (China) established the joint venture company which would engage in the comprehensive business including the real estate development in some north cities of China.

\subsection{Industrial actuality of policy in China}

Though China has issued many basic laws and regulations aiming at the trust industry, but the special laws and regulations aiming at REITs have not been issued at present. The private equity laws are complete, and the private equity is supported by the state and local governments, and it is free to develop the REPE without any legal obstacles in essential.

There are many documents of basic laws and regulations to support the development of the trust industry. The "Trust Law of China" was implemented in Oct of 2001, and the "Administrative Measure of Trust Company", the "Gathering Capital Trust Planned Administrative Method of Trust Companies", and the "Administrative Guidance of Trust Companies" were put into force in March of 2007. And the "Gathering Capital Trust Planned Administrative Method of Trust Companies" prescribed a limit to eligible investors.

The special policy documents of REITs are still in the research stage, but as a kind of financing channel, REITs has been noticed by policies. CBRC called five trust companies together to draw up the exposure draft of "Administrative Measure of Trust Company (Draft)". The "State Financial Nine Articles" and "State Financial Thirty Articles" of State Council of China all definitely put forward to develop the experiment unit of REITs, and widen the financing channels of real estate enterprises.

Comparing with REITs, the legal platform of developing the private equity of REPE is complete, without essential legal obstacles. The revise of a series of law and regulation such as "Company Law of PRC", "PRC Partnership Enterprise Law", "Interim Administration Measures for Venture Capital Enterprises", and "Management Methods of Securities Registration and Clearing", and the issuance of relative administration methods provide good legal environment for the development of the private equity fund. The reform of the shareholder structure, the implementation of the growth enterprise market, and the implementation of the partnership enterprise securities 
account all create more convenient channels for the investment and exit of private equity funds. The state also encourages the development of the private equity investment enterprise, and gives them many tax preference policies. Many local governments also issued many preference policies to encourage the equity investment enterprises to settle in the local places.

\section{Application obstacles and advices of REITs and REPE}

\subsection{Related laws}

Though there are many laws and regulations about the trust industry, which have loosen the limitation for investors, but the legal environment is still too far to develop REITs. According to the existing policies, the transfer of the mortgaged or securitized property right of real estate must be embodied by the form of filling in the property right registration institution. But this filling has not corresponding legal effect, and one the disputes occur, investors' rights and interests cannot be protected. The large obstacle for the development of REITs is that the investment trust fund of real state cannot be listed in the market of China.

Therefore, the laws and regulations about the real estate trust should be perfected first, and USA and Japan's experience can be used for references because both of them have developed REITs and mature laws, such as American Securities Act in 1933, Securities Trading Act in 1934, Investment Counseling Act in 1940, Real Estate Investment Trust Bills in 1960, and REIT Modernization Bills in 1999, and Japanese Securities Investment Trust Law, Securities Trading Law, Trust Law, Trust Industry Law and Securities Investment Counselor Law. The existing Securities Investment Fund Law of RPC cannot standardize the industrial investment funds, and the "Industrial Investment Fund Law" should be constituted as quickly as possible, and the management systems about the real estate property right registration and trading shod be complemented and revised at the same time.

\subsection{Taxation system}

In China, in the operation of real estate investment funds, the corporate fund taxation includes double taxes such as fund layer and the investor layer. The fund layer also involves the tax categories aiming at various trading behaviors in the fund operation except for the property tax and the income tax, and the investor layer mainly means the income tax. The trust-type fund or the limited partnership-type fund only need collecting tax on the investor layer. But in USA, most REITs belong to the corporate type, and to encourage the development of funds, the income tax is free on the fund layer. In China, most REPEs adopt the limited partnership system, and the government only collects the income tax on the investor layer, and the corporate-type REITs need be collected for double taxes. To avoid the taxation, REITs will adopt the trust system, which will restrain the scale development of REITs. Therefore, the USA mode or the Asian mode can be used for references, and the government should issue beneficial tariff policies or special taxation documents aiming at REITs, and confirm the single-layer taxation for the corporate-type REITs. That can use the "Domestic Taxation Act of USA in 1960" and the "Taxation Reform Law in 1986" for references.

\subsection{Supervision system}

The direct supervision department of the trust industry in China is CBRC, but because REITs have not been pushed formally, the supervision department has not been finally confirmed. PE has been developed quickly, and the legal laws and regulations need to be perfected further, without sufficient industrial self-regulation, and the holes still exist in the industrial supervision. PE has not been brought into the supervision range formally, and at present, only some PE enterprises according with certain conditions would put on records in NDRC, without enforceability. Without effective supervision systems, the private equity will invest blindly to some extent and harm investors' rights and interests. PE in China still lack in some industrial rules, and the quick development of PE attracts many new investors without any investment experiences, and these investors' qualities are intermingled. If these problems cannot be changed, the investment return and scale of Chinese private equity will be impacted.

To pave the way for experiment unit of REITs, the supervision and administration system involving CBRC and CSRC (China Securities Regulatory Commission) should be constituted, to clearly define the trust companies, the investors, the trusteeship banks, and the investment objects' rights and obligations, set up specific admittance system for institutions, projects, and jobholders, and enhance the market entrance threshold of REITs to restrain possible risks and foams. The government should fully use international experiences for references, and establish the supervision and administration system combining the government supervision with the industrial self-regulation under the legal limitation based on the actuality of China. Though PE mainly adopts the self-regulation mode, but relative laws and regulations should be revised as quickly as possible to bring PE into the supervision and administration range of the government. The Fund Law of RPC is being revised, and it will bring the PE into the supervision range. In addition, the information disclosure system should be perfected, and when REITs collect the capitals in the market, many important items such as the trust capital collection, the trust asset management and 
utilization, the income distribution, and the related transaction should be announced on the appointed mediums to protect investors' rights and interests. For REPE, the relative guidance to disclose the information about the process of the capital collection and management should be instituted to protection special investors' rights and interests and avoid fund managers' operation risk and moral risk.

\subsection{Professional talents}

Both REITs and REPE need the talents who not only know the real estate, but also master financial investment knowledge. But in the practice, the talents who are good at the professional technology and projects of real estate always lack in the experiences in the asset operation and the financial management ability, and the talents who good at the financial investment always are unfamiliar in the operation of real estates. The talents of REPE mainly come from these two directions, and the composite talents are deficient. Without professional talents, the fund investment cannot obtain reasonable yield, and investors will not invest in the real estate funds, and the development of REITs in China will be restrained, influencing the yield of REPE. Therefore, to develop REITs and REPE in certain scale, the talent cultivation of the real estate trust investment fund needs to be further strengthened. The professional management talent team which members can master the fund operation, know the real estate market, and be familiar with the operation of business should be established urgently. Other service talents such as lawyers, accountants, auditors, and appraisers matched with this industry should also enrich their own personal knowledge and operation ability according to the characteristics of REITs and REPE.

\subsection{Others}

REITs must have rigorous organizational institutions, including management committee, supervision institutions, and concrete operation institutions. REPE is based on the private equity, with mature organizational structure, but it should combine with the industrial background of real estate to operation. To perfect the financial market system, the diversified investment institution composed by the real estate credit department of commercial banks, the house bank, the mortgage bank, the trust bank, and the real estate trust investment company should be cultivated, and the real estate evaluation institution and the real estate securities grading evaluation institution should be developed at the same time.

\section{References}

Cannon Susanne and Stephen Vogt. (1995). REITs and their management: An analysis of organizational structure, performance and management compensation. Journal of Real Estate Research. No. 10. P. 297-317.

Du, Jiang. (2005). Discrimination of the Real Estate Investment Fund Concept and the Actual Selection. Technology and Market. No. 7. P. 53-55.

Garrigan and Parsons. (1997). Real Estate Investment Trusts. McGraw-Hill REIT.

Jaffe, J.F. (1991). Taxes and the Capital Structure of Partnerships, REITs and Related Entities. Journal of Finance. No. 1. P. 911-922.

Pan, Guoquan. (2006). Development and Revelations of the Real Estate Investment Trusts in USA. China Science and Technology Information. No. 4. P. 175-176.

Ralph Brock. (2007). Real Estate Investment Trusts. Beijing: China Citic Press.

Song, Yanhua \& Ying, Zhenxiang. (2004). Study on the Environment Support System of Real Estate Investment Trust. Optimization of Capital Construction. No. 25(6). P. 35-41.

Wang, Hui. (2008). Thinking about How to Develop and Perfect the Real Estate Investment Trust. Social Scientist. No. 138(10). P. 111-114.

Wang, Yongsheng \& Zhang, Baoting. (2008). Study on the Taxation of the Real Estate Investment Fund. Tianjin Economy. No. 5. P. 65-67.

Yang, Guangbin. (2007). Research in Development of Real Estate Investment Trust Financing in China. Value Engineering. No. 2. P. 143-145.

Zhang, Jian. (2010). How to Exactly Know the Real Estate Investment Trust Funds. Chinese Territory Resource News. March 2, 2010. 